\title{
Fabrication of Mesoporous NaZrP Cation-Exchanger for U(VI) Ions Separation from Uranyl Leach Liquors
}

\author{
Islam G. Alhindawy ${ }^{1}$, Emad A. Elshehy ${ }^{1, *}$ (D) Mohamed E. El-Khouly ${ }^{2,3}$, \\ Yasser K. Abdel-Monem ${ }^{4}$ and Mohamed S. Atrees ${ }^{1}$ \\ 1 Nuclear Materials Authority, P.O. Box 530, El-Maadi, Cairo 11936, Egypt; \\ islam.alhindawy@gmail.com (I.G.A.); msatrees@yahoo.com (M.S.A.) \\ 2 Department of Chemistry, Faculty of Science, Kafrelsheikh University, Kafr El-Sheikh 33516, Egypt; \\ mohamed.elkhouly@yahoo.com \\ 3 Institute of Basic and Applied Sciences, Egypt-Japan University of Science and Technology, New Borg \\ El-Arab City, Alexandria 21500, Egypt \\ 4 Department of Chemistry, Faculty of Science, Menoufia University, Shebin El-Kom 32511, Egypt; \\ ykabdelmonem@gmail.com \\ * Correspondence: eelshehy@yahoo.com; Tel.: +20-1008197997
}

Received: 5 August 2019; Accepted: 2 October 2019; Published: 8 October 2019

\begin{abstract}
As the demand for uranium production-based energy worldwide has been increasing in the last decades to maintain nuclear growth for electricity production, there are great efforts towards developing an easy and inexpensive method for uranium extraction and separation from its ores. For this purpose, mesoporous inorganic cation exchangers provide an efficient separation technology that can help streamline production and lower overall cost. This study describes the development of nano-structured mesoporous sodium zirconium phosphate (NaZrP-CEX) for separation and extraction of uranyl ions from real samples. The fabricated NaZrP-CEX was well characterized by various techniques such as X-ray diffraction (XRD), Fourier Transform Infrared (FTIR), Scanning Electron Microscope (SEM), $\mathrm{N}_{2}$ adsorption/desorption, Dynamic light scattering (DLS) and zeta potential). The kinetics/thermodynamic behaviors of uranyl ion adsorption into NaZrP-CEX from an aqueous solution were minutely studied. The kinetic studies showed that the pseudo-second order model gave a better description for the uptake process. The negative value of $\Delta \mathrm{G}$ indicate high feasibility and spontaneity of adsorption. Finally, mesoporous NaZrP-CEX can be regenerated using both of $\mathrm{HNO}_{3}(0.05 \mathrm{M})$ or $\mathrm{HCl}(1 \mathrm{M})$ up to seven cycles of operation.
\end{abstract}

Keywords: mesoporous materials; zircon processing; sodium zirconium phosphate; leaching; adsorption; ion exchange; uranyl ions

\section{Introduction}

Extraction of uranium has been quite important in the recent years for production of electricity, as well as producing industrial and medical isotopes [1]. As is well known, uranium is one of the naturally occurring actinides with an average concentration of $2.8 \mathrm{ppm}$ in the Earth's crust and found in as tetravalent and hexavalent ions [2,3]. Huge quantities of uranium exist in seawaters ( $3 \mu \mathrm{g} / \mathrm{L})$ [4-6]. A few of it is obtained as by-product from other industries, such as the gold and phosphate production [7-10]. The necessity to produce large quantities of uranium from real mines has resulted in the headway of the extraction techniques [7-11]. The various techniques used for extraction and separation of uranium include precipitation, solvent extraction and adsorption attracted much attention in the last decades [7-14]. Therefore, adsorption was found to be a potential method for removal and extraction of metal ion from effluents because of its low operational and maintenance costs [15-17]. 
In the recent years, well-defined porous materials have been of great interest in various applications (e.g., adsorption, catalysis and sensors) due to their excellent structural properties, ease of fabrication, and low-cost approach [18,19]. The porosity in these types of materials are enhancing the surface area and simplifying its way to interact with surroundings $[18,19]$. Particularly, the use of inorganic mesoporous adsorbents is a promising way to formularize simple and cost-effective protocols with high sensitivity and selective uptake of target species [20-25]. Compared with the organic exchangers, the inorganic exchangers have advantages of high thermal stability and durability for many reuse cycles. From the extraction industry point of view, the utilized inorganic exchanger should have innumerable features, unique atomic arrangements in the walls with thermally and hydrothermally stable, nanoscale particle size, high surface area and pore volume, and well-defined active sites.

Among the various inorganic meso-sorbents, zirconium phosphate $(\mathrm{ZrP})$ and sodium zirconium phosphate $(\mathrm{NaZrP})$ attracted much attention as an efficient ion-exchanger for sequestering radioactive materials depending on $\mathrm{pH}$ values [26-32]. In particular, mesoporous NaZrP represent a class of material having ability for recovery of uranyl ions from its real aqueous samples at specific $\mathrm{pH}$ value for their high adsorption activity, durability in both acidic and basic media, as well as their non-flexible and intensive adsorption design strategies [30-32]. According to the best of our information's, the utilization of mesoporous $\mathrm{NaZrP}$ for recovery of uranium from mining samples is rare in the literature.

Toward this goal, we report herein the fabrication and characterization of mesoporous NaZrP from Egyptian Rosetta zircon mineral, keeping in mind that: (i) the phosphate group in zirconium phosphate mesostructured is considered as a promising unit for a high-sensitivity cation exchanger for uranyl ions, (ii) the adsorption mechanism of uranyl ions on NaZrP pore surfaces, based on active sites containing hydrogen and sodium ions can be replaced by uranyl ions [29], (iii) the surface area morphology and pore cavities are the key factors to controlling the diffusion and adsorption of large quantities of uranyl ions onto exterior and interior surface of the mesopores. The batch adsorption experiments were carried out with variation in initial $\mathrm{pHs}$ concentration of uranyl ions, contact time and temperature. In addition, we determined both the kinetic and thermodynamic characteristics of uranyl ion adsorption onto mesoporous NaZrP-CEX that can be helpful to exploit the future commercial viability of the fabricated material from the real ores. The regeneration of loaded NaZrP-CEX with uranyl ions was also evaluated to signify a multi-use application.

\section{Materials and Methods}

\subsection{Chemicals}

Zirconium oxychloride $\left(\mathrm{ZrOCl}_{2} \cdot 8 \mathrm{H}_{2} \mathrm{O}\right)$ was obtained from the Egyptian Rosetta zircon mineral $\left(\mathrm{ZrSiO}_{4}\right.$, purity $97 \%$ ) via alkali fusion with sodium hydroxide (purity 95.9\%) followed with treatment with hydrochloric acid $(\mathrm{HCl})$. All other materials were of analytical grade and used without further purification. Ammonium dihydrogen phosphate $\left(\mathrm{Na}_{2} \mathrm{HPO}_{4}\right)$, phosphoric acid $\left(\mathrm{H}_{3} \mathrm{PO}_{4}\right)$, hydrofluoric acid (HF), hydrochloric acid, sodium lauryl sulfate (SLS), ethanol and urea were ADWIC products, Egypt. The $\mathrm{pH}$ values of the solutions were adjusted by using $0.01 \mathrm{~mol} \mathrm{~L}^{-1}$ nitric acid or $0.01 \mathrm{~mol} \mathrm{~L}^{-1}$ sodium hydroxide solutions.

\subsection{Fabrication of Commercial Mesoporous NaZrP-CEX}

The fabrication of commercial mesoporous sodium zirconium phosphate ion-exchanger from zircon was carried out in three main steps, as follows: (i) a sample of $1 \mathrm{~g}$ of Rosetta zircon concentrate was mixed with $1.25 \mathrm{~g}$ of sodium hydroxide and charged to a 316-L stainless steel high pressure crucible (height $=5 \mathrm{~cm}$, diameter $=1.5 \mathrm{~cm}$ ). The crucible was then fed to the electric furnace where the fusion reaction took place [33]. The reaction temperature was adjusted at $500{ }^{\circ} \mathrm{C}$ and continued for $1 \mathrm{~h}$. The fusion product was washed and stirred for $2 \mathrm{~h}$ to dissolve the water soluble sodium silicate formed $\left(\mathrm{Na}_{2} \mathrm{SiO}_{3}\right)$. The mixture was filtrated out, and the residue $\left(\mathrm{Na}_{2} \mathrm{ZrO}_{3}\right)$ washed several times with DIW and dried at $70{ }^{\circ} \mathrm{C}$. (ii) Then, $1 \mathrm{~g}$ of the dried sodium zirconate was leached with $\mathrm{HCl}(12 \mathrm{M})$ to produce 
zirconium oxychloride $\left(\mathrm{ZrOCl}_{2} \cdot 8 \mathrm{H}_{2} \mathrm{O}\right)$, which turned into the crystalline form by cooling the solution. The formed crystals were separated from the mother liquor by decantation followed by filtration and finally drying in air to obtain white powder crystals of $\mathrm{ZrOCl}_{2} \cdot 8 \mathrm{H}_{2} \mathrm{O}$. (iii) The mesoporous $\mathrm{NaZrP}$ was prepared by a hydrothermal reaction, as following; $1 \mathrm{~g}$ of $\mathrm{ZrOCl}_{2} \cdot 8 \mathrm{H}_{2} \mathrm{O}$ prepared in step (ii) was mixed with $0.5 \mathrm{~mL}$ of $\mathrm{H}_{3} \mathrm{PO}_{4}(85 \mathrm{wt} \%$ solution) and $0.2 \mathrm{~mL} \mathrm{HF}$ then $15 \mathrm{~mL}$ DIW was added. To this solution, add $0.75 \mathrm{~g} \mathrm{Na}_{2} \mathrm{HPO}_{4}$ and $0.55 \mathrm{~g}$ SLS, and finally add $0.4 \mathrm{~g}$ urea with continuous stirring for $30 \mathrm{~min}$. The resulting gelatinous mixture was transferred into a $25 \mathrm{~mL}$ capacity Teflon-lined stainless steel autoclave. The autoclave was sealed and heated at $175^{\circ} \mathrm{C}$ for $5 \mathrm{~h}$. The molar ratio of the $\mathrm{ZrOCl}_{2} \cdot 8 \mathrm{H}_{2} \mathrm{O}: \mathrm{H}_{3} \mathrm{PO}_{4}: \mathrm{NaH}_{2} \mathrm{PO}_{4} \cdot 7 \mathrm{H}_{2} \mathrm{O}: \mathrm{HF}$ : SLS: urea was 1:0.2:0.45:0.3. The precipitate was collected by filtration and washed several times with DIW and ethanol to remove the remaining agents. Finally, the as made $\mathrm{NaZrP}$ was dried at $60{ }^{\circ} \mathrm{C}$ for $3 \mathrm{~h}$ in the vacuum oven and carefully calcined in air by heating rate $2{ }^{\circ} \mathrm{C} / \mathrm{min}$ from room temperature up to $350^{\circ} \mathrm{C}$ for $30 \mathrm{~min}$ then increasing the temperature to $600{ }^{\circ} \mathrm{C}$ for $5 \mathrm{~h}$ to obtain mesoporous zirconium phosphate ion-exchanger (NaZrP-CEX).

\subsection{Materials Characterization}

Fourier Transform Infrared (FTIR) spectra were performed in KBr discs using Nexeus-Nicolite model 640-MSA. FTIR, Thermo Electronics Co. (USA). X-ray diffraction (XRD) analyses were carried out with a Philips X-ray generator model PW $3710=31$. The particle size distribution of the fabricated ZrP-CEX were evaluated through dynamic light scattering (DLS). The zeta potential was measured using a Nano Series Zeta Sizer, Malvern; Worcestershire, UK. The uranium ion concentration was determined using 720-ICP-OES (Agilent Technologies) Inductively Coupled Plasma-Optical Emission Spectrometer (ICP-OES). The textural properties of the mesoporous NaZrP-CEX including the specific surface area, pore volume and the pore structure were determined by $\mathrm{N}_{2}$ adsorption technique using a BELSORP MIN-II analyzer (JP. BEL Co. Ltd.) at $77 \mathrm{~K}$. Transmission electron microscopy (TEM), and energy dispersive $X$-ray spectroscopy for elemental mapping (STEM-EDS) were performed using a JEOL JEM model 2100F microscope.

\subsection{Batch Studies for Uranyl Ions Adsorption Assays}

In a typical metal ion adsorption experiments, the estimation of the appropriate $\mathrm{pH}$ value for the adsorption of uranyl ions on the fabricated NaZrP-CEX ion-exchanger was carried out as follows: a $20 \mathrm{mg}$ of mesoporous NaZrP-CEX were immersed in $20 \mathrm{~mL}$ solution containing $100 \mathrm{mg} / \mathrm{L}$ uranyl ion concentrations adjusted at varied $\mathrm{pH}$ values ranged from 1-7 and were shacked using an orbital shaker in a temperature-controlled water bath at $25^{\circ} \mathrm{C}$ for $3 \mathrm{~h}$ at a constant agitation speed of $300 \mathrm{rpm}$. After equilibration, the mixture was filtered and the filtrate containing uranyl ions was analyzed for adsorption assessment. After estimation of the appropriate $\mathrm{pH}$ value for the adsorption process, other experiments, like effect of contact time, uranyl ions concentration, solution temperatures, $\mathrm{NaZrP}-\mathrm{CEX}$ dosage were conducted according to the estimated $\mathrm{pH}$ value. The effect of contact time was carried out by immersing $20 \mathrm{mg}$ of NaZrP-CEX in $20 \mathrm{~mL}$ solution of $100 \mathrm{mg} / \mathrm{L}$ uranyl ions and the $\mathrm{pH}$ was adjusted up to 4.5 at $25^{\circ} \mathrm{C}$ with time-variation from 1-240 min. In adsorption isotherm studies, NaZrP-CEX $(20 \mathrm{mg})$ was also immersed in a mixture of specific ion concentrations and adjusted to specific $\mathrm{pH}$ values (4.5) in $20 \mathrm{~mL}$ solution volume while stirring for $2 \mathrm{~h}$ at 25,35 and $45^{\circ} \mathrm{C}$. Generally, the adsorption capacity (mg/L) and the sorption efficiency (\%) of NaZrP-CEX loaded with uranyl ions were estimated according to Equations (1) and (2) [22,23]:

$$
\begin{aligned}
\mathrm{q}_{\mathrm{e}} & =\frac{\left(\mathrm{C}_{\mathrm{i}}-\mathrm{C}_{\mathrm{e}}\right) \mathrm{V}}{\mathrm{m}} \\
\mathrm{R} \% & =\frac{\left(\mathrm{C}_{\mathrm{i}}-\mathrm{C}_{\mathrm{e}}\right) 100}{\mathrm{C}_{\mathrm{i}}}
\end{aligned}
$$


where $\mathrm{q}_{\mathrm{e}}$ is the uranyl ions uptake $\left(\mathrm{mg} \mathrm{g}^{-1}\right), \mathrm{V}$ is the solution volume $(\mathrm{L}), \mathrm{m}$ is the mass of the NaZrP-CEX $(\mathrm{g})$, and $\mathrm{C}_{\mathrm{i}}$ and $\mathrm{C}_{\mathrm{e}}$ are the initial and equilibrium concentrations of the uranyl ion $\left(\mathrm{mg} \mathrm{L}^{-1}\right)$, respectively. The effect of co-existing cations on uranyl ion sorption onto the adsorbent was evaluated. The initial concentration of uranyl was $1 \mathrm{mg} \mathrm{L}^{-1}$, while the competing ions were $5 \mathrm{mg} \mathrm{L}^{-1}$. After dissolving competing ions in the solutions with uranyl ions, sorption experiments were performed in the same manner according to the sorption experiment.

\section{Results and Discussion}

\subsection{Fabrication and Characterization of NaZrP-CEX}

For fabrication, zirconium oxychloride was firstly obtained from Egyptian zircon as the precursor material for synthesis of sodium zirconium phosphate via a simple hydrothermal synthesis. The substitution reaction between $\mathrm{ZrOCl}_{2} \cdot 8 \mathrm{H}_{2} \mathrm{O}$ and a mixture of $\mathrm{H}_{3} \mathrm{PO}_{4} / \mathrm{NaH}_{2} \mathrm{PO}_{4}$ assisted with SLS heated up to $175^{\circ} \mathrm{C}$ for $5 \mathrm{~h}$. After calcination up to $550{ }^{\circ} \mathrm{C}$, the fabricated material appears to be a mesoporous crystalline sodium zirconium phosphate $(\mathrm{NaZrP})$. The $\mathrm{XRD}$ patterns of sodium zirconium phosphates $(\mathrm{NaZrP})$ are shown in Figure 1a. It can be seen that NaZrP shows several prominent reflections at about $2 \theta$ values of $20.77^{\circ}, 29.34^{\circ}, 30.4^{\circ}, 34.93^{\circ}, 42.3^{\circ}, 47^{\circ}, 54^{\circ}, 73.67^{\circ}, 95.5^{\circ}$ and $97.52^{\circ}$. These values are well consistent with the earlier determined patterns of sodium zirconium phosphate $\mathrm{NaZr}_{2}\left(\mathrm{PO}_{4}\right)_{2}$ with hexagonal crystal system [30,31]. This finding match with JCPDS powder diffraction data file no. 33-1312. The diffractogram shows the emergence of $\mathrm{NaZr}_{2}\left(\mathrm{PO}_{4}\right)_{3}$ (major phase) and $\mathrm{ZrSiO}_{4}$, (minor phase). It should be noted that there are no strong reflexes corresponding to unreacted precursors. It is confirmed that $\mathrm{NaZr}_{2}\left(\mathrm{PO}_{4}\right)_{3}$ is favorably obtained after releasing of all organic matter from as-synthesized SLS/NaZrP at temperatures up to $550{ }^{\circ} \mathrm{C}$.
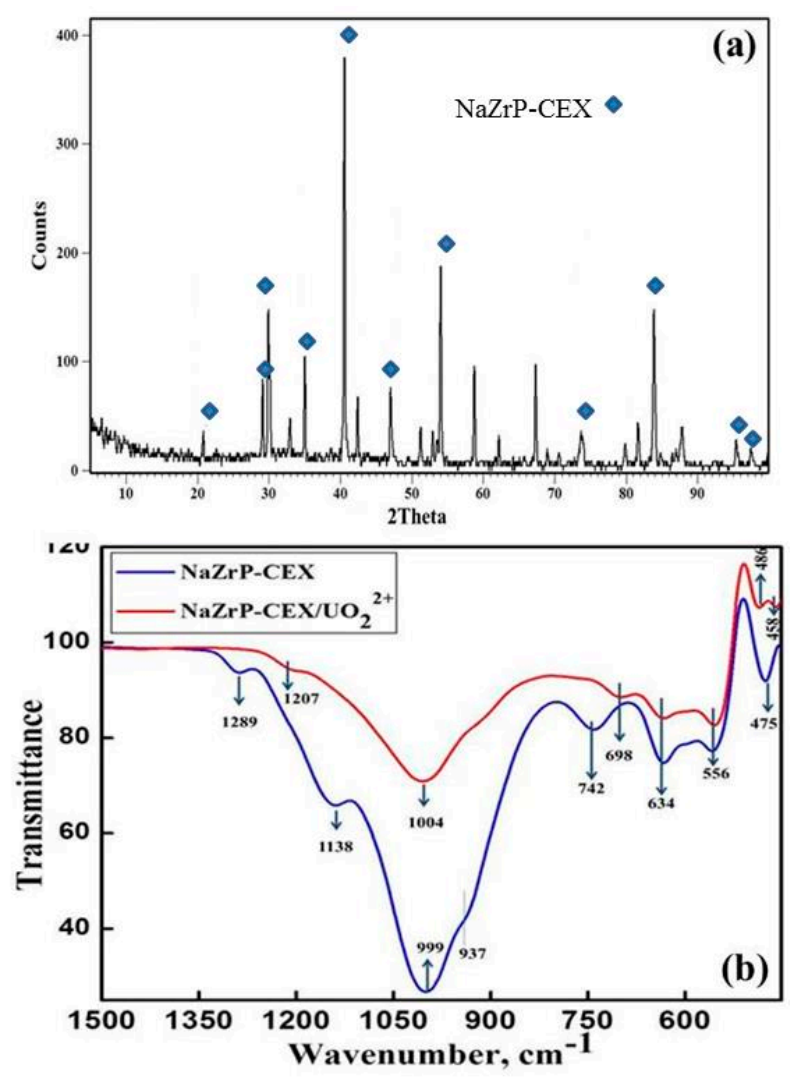

Figure 1. (a) Representative X-ray diffraction (XRD) pattern for the synthesized mesoporous zirconium phosphate ion-exchanger (NaZrP-CEX) and (b) Fourier Transform Infrared (FTIR) spectra for the synthesized NaZrP-CEX and NaZrP-CEX loaded uranyl ions. 
The typical IR spectra of the synthesized NaZrP-CEX and NaZrP-CEX/ $/ \mathrm{UO}_{2}{ }^{+2}$ are depicted in Figure 1b. The IR spectrum of NaZrP-CEX exhibited the sharp band at $999 \mathrm{~cm}^{-1}$ that was assigned to $\mathrm{P}-\mathrm{O}$ stretching vibrations of $\mathrm{PO}_{4}{ }^{3-}$ groups. The recorded bands at 556 and $634 \mathrm{~cm}^{-1}$ could be attributed to $\mathrm{PO}_{4}$ tetrahedron [27,32]. This stretching can be influenced by the presence of alkali ions like Na presence in ZrP-CEX framework [32]. The success of uranium loading on NaZrP-CEX was clearly detected by recording the shift and decrease in the intensity of $\left(\mathrm{PO}_{3}\right)^{2-}$ band at $1004 \mathrm{~cm}^{-1}$ as the concentrations of uranium increases in NaZrP-CEX/ $/ \mathrm{UO}_{2}{ }^{+2}$ [27]. Furthermore, the recorded band at $458 \mathrm{~cm}^{-1}$ can be assigned to the stretching of $\mathrm{U}(\mathrm{VI})-\mathrm{O}$. The bands at 937 and $742 \mathrm{~cm}^{-1}$ may be associated with asymmetric and symmetric stretching of the P-O-P bonds [22]. FT-IR spectrum of $\mathrm{NaZrP-CEX} / \mathrm{UO}_{2}{ }^{+2}$ shows that both the intensity and the position of absorption band at $1004 \mathrm{~cm}^{-1}$ have been changed due to uranyl ions adsorptions. In addition, the band at $475 \mathrm{~cm}^{-1}$ was also subsiding after uranyl ions adsorption indicating the involvement of $\mathrm{Na}_{-} \mathrm{PO}_{4}{ }^{-}$groups in the adsorption mechanism of uranium ions. In the difference FTIR spectrum of the NAZP-CEX, one can see the distinctive band at $1289 \mathrm{~cm}^{-1}$ that is disappeared after adsorption of uranium [32].

The surface properties of sodium zirconium phosphate are presented in Figure 2a. The BET surface area of the NaZrP-CEX was found to be $88.5 \mathrm{~m}^{2} / \mathrm{g}$ and has been decreased to $51.3 \mathrm{~m}^{2} / \mathrm{g}$ after uranium adsorption due to pore blocking with uranyl ions. As seen from Figure $2 \mathrm{a}$, the nitrogen adsorption/desorption isotherm of the free NaZrP-CEX and NaZrP-CEX loaded uranyl ions exhibited a typical "type IV" isotherm shape with a H3 hysteresis loop indicated that the sample was a typical of high quality mesoporous materials and the hysteresis loops shift to higher relative pressure $\left(\mathrm{P} / \mathrm{P}_{0}>0.4\right)$, implying indicative of a larger pore size. Furthermore, the surface area $\left(88.5 \mathrm{~m}^{2} / \mathrm{g}\right)$, pore volume $\left(0.569 \mathrm{~cm}^{3} / \mathrm{g}\right)$ and large pore size $(20.75 \mathrm{~nm})$ of this material are great advantages in the fabrication of sodium zirconium phosphate as mesoporous sorbent that intake ultra-trace amounts of uranyl ions. A comparative study in terms of texture properties has been carried out with other reported NaZrP materials synthesized by different methods, and the results are summarized in Table 1.
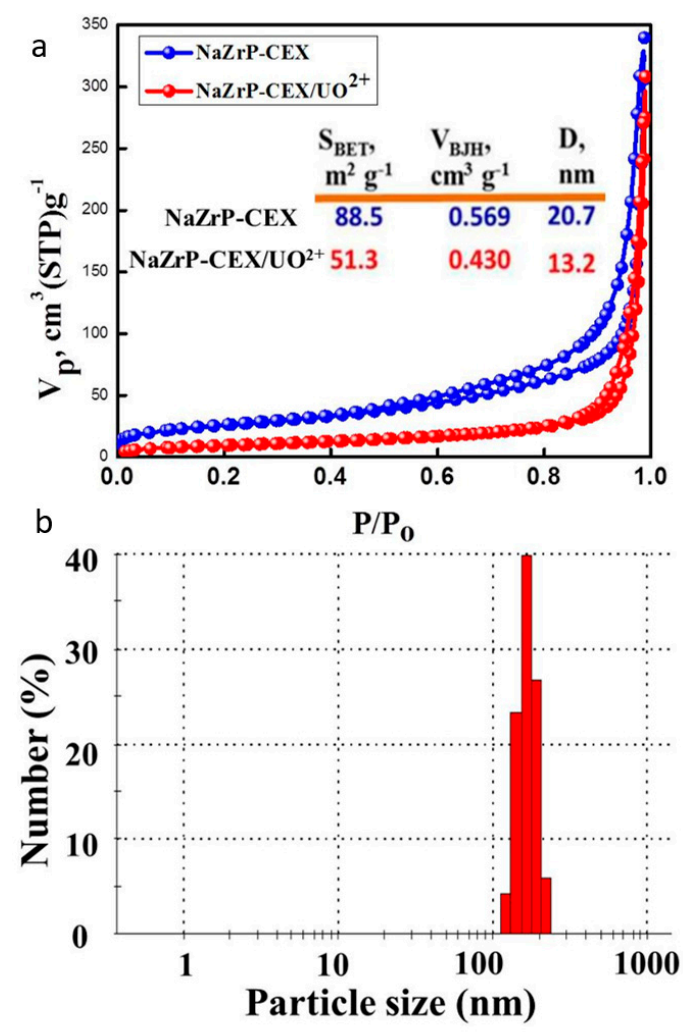

Figure 2. (a) $\mathrm{N}_{2}$ adsorption-desorption isotherm; surface area $\left(\mathrm{S}_{\mathrm{BET}}\right)$, pore volume $\left(\mathrm{V}_{\mathrm{BJH}}\right)$ and pore diameter (inset). (b) Particle size distribution of the mesoporous NAZrP-CEX particles. 
The morphology of NaZrP-CEX was elucidated using the scanning electron microscope (SEM). Figure 3a,b shows pronounced sheets of NaZP-CEX particles with average sizes ranging from 140-190 $\mathrm{nm}$ that is well consistent with the particle size distribution shown in Figure $2 \mathrm{~b}$. Moreover, the observed particles on NaZrP-CEX sheets (Figure 3c) show that the $\mathrm{UO}_{2}{ }^{2+}$ ions were homogeneously adsorbed with extensive three-dimensional aggregation. EDX of NaZrP indicated the presence of EDX of NaZrP-CEX referred to the presence of O (43.5\%), P (25.7\%) and $\mathrm{Na}(16.5 \%)$ in the NaZrP-CEX composition domains of the sodium zirconium phosphate meso-structure (Figure 3d).
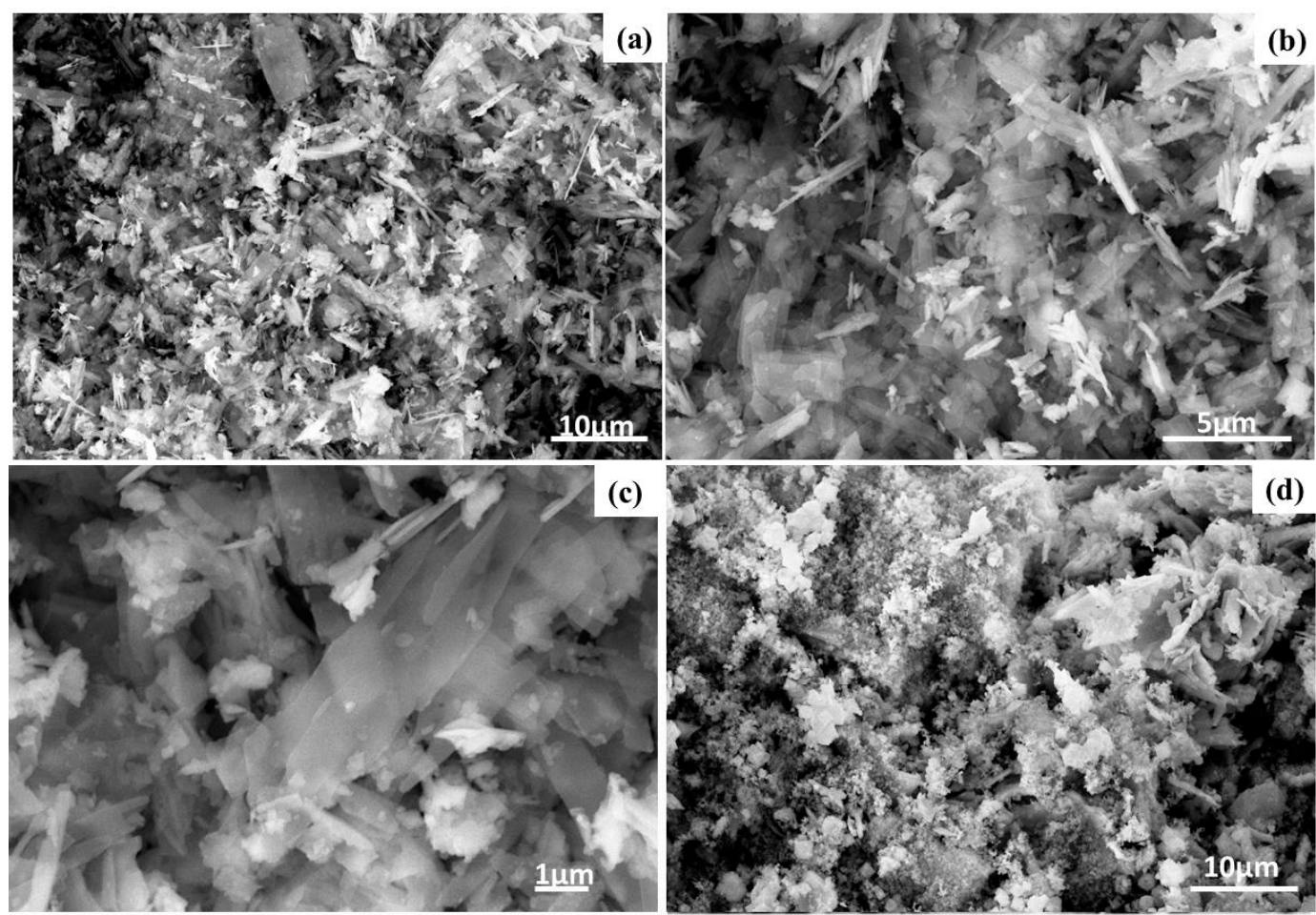

(b)
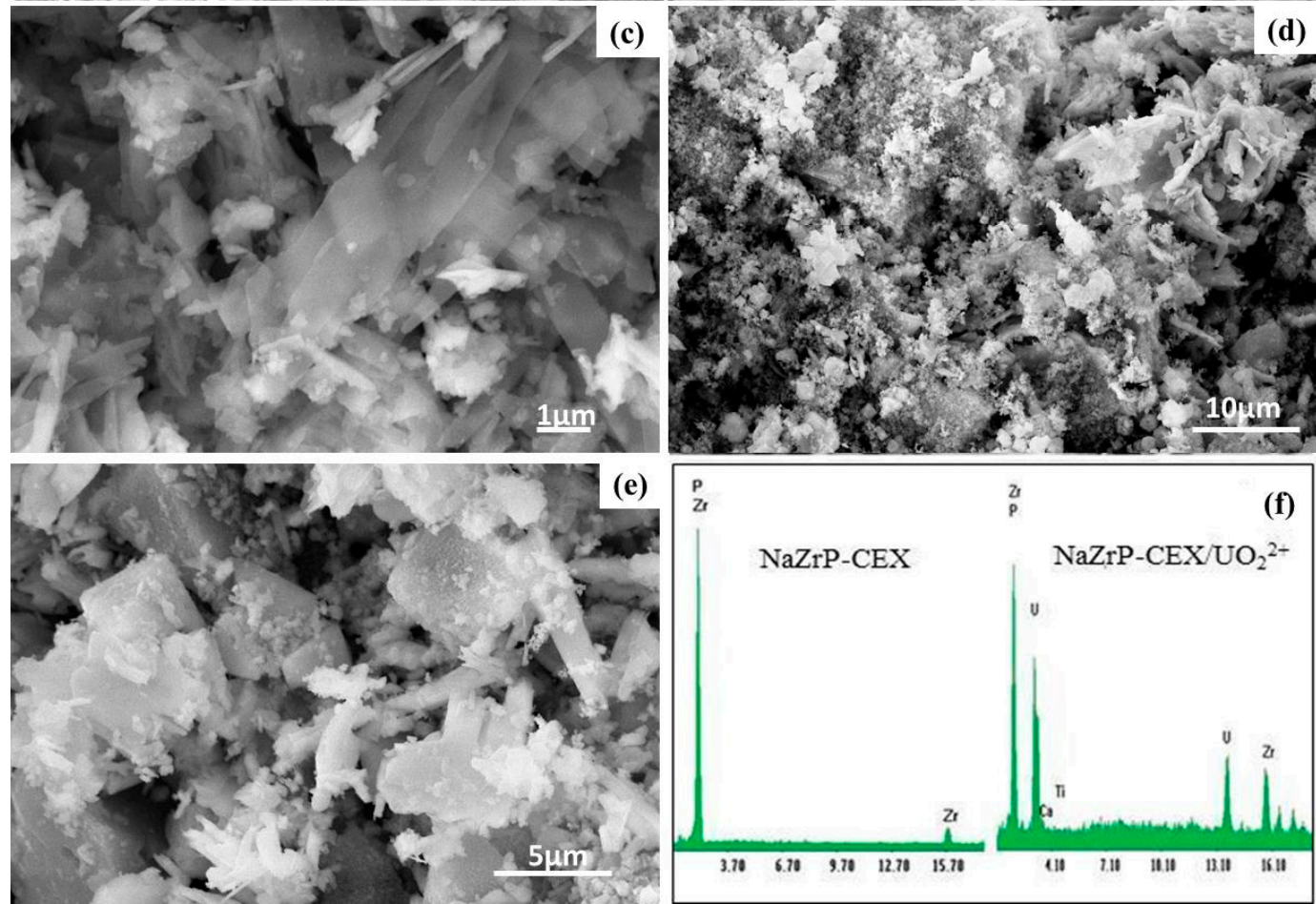

(d)

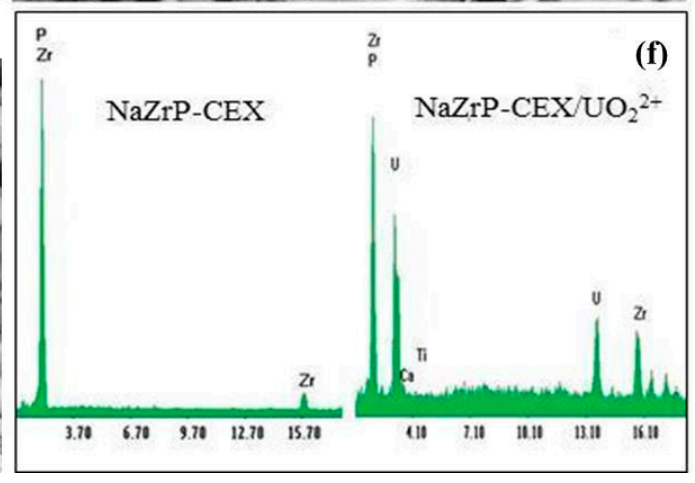

Figure 3. Scanning Electron Microscope (SEM) images of the fabricated mesoporous NaZrP-CEX with different magnifications (a-c), NaZrP-CEX loaded uranyl ions (d,e), and EDX analysis of NaZrP-CEX and NaZrP-CEX loaded uranyl ions (f). 
Table 1. Comparison of the surface area the fabricated adsorbent mesoporous zirconium phosphate ion-exchanger (NaZrP-CEX) with the previously reported NaZrP materials.

\begin{tabular}{llcc}
\hline \multicolumn{1}{c}{ Method of Preparation } & \multicolumn{1}{c}{ Application } & Surface Area & Ref. \\
\hline Sol-Gel & Antibacterial activity & 5.10 & {$[34]$} \\
Co-precipitation & Sorbent dialysis & 1.9 & {$[35]$} \\
Sol-gel & Antibacterial activity & 5.24 & {$[36]$} \\
Sol-gel & Catalytic activity & 26.8 & {$[37]$} \\
Sol-gel & Catalytic activity & 63 & {$[38]$} \\
Evaporative decomposition of solutions & - & 29.2 & {$[39]$} \\
Hydrothermal & Uranium adsorption & 88.5 & Our Work \\
\hline
\end{tabular}

\subsection{Batch Adsorption Studies of Uranyl Ions on ZrP-CEX}

\subsubsection{Effect of $\mathrm{pH}$}

The $\mathrm{pH}$ is one of the main factors which play an important role in controlling the adsorption process of the $\mathrm{UO}_{2}{ }^{2+}$ ions through affecting both the electrical charge of NaZrP-CEX and the uranium speciation in the solutions. Figure 4 a shows the effect of $\mathrm{pH}$, in the range of 1.0-5.0, with a fixed weight of the NaZrP-CEX (20 mg) and $20 \mathrm{~mL}$ solution volume of $100 \mathrm{mg} \mathrm{L}^{-1} \mathrm{UO}_{2}{ }^{2+}$ ions at $25^{\circ} \mathrm{C}$ for $3 \mathrm{~h}$ contact time. The adsorption of $\mathrm{UO}_{2}{ }^{2+}$ ions depends on the uranium speciation/surface charge in solution at specific $\mathrm{pH}$ values. Uranium can be hydrolyzed into different mono-nuclear and poly-nuclear hydrolyzed species in the form of $\left[\left(\mathrm{UO}_{2}\right)_{\mathrm{m}}(\mathrm{OH})_{\mathrm{n}}\right]^{(2 \mathrm{~m}-\mathrm{n})+}[3]$. As $\mathrm{pH}<4.0, \mathrm{UO}_{2}{ }^{2+}$ ions in aqueous solution exist predominantly as monomeric species. The observed lower uptake values for uranyl ions at lower $\mathrm{pHs}$ is due to the formation of hydronium ions closely associated with NaZr-CEX and the overall surface charge on the NaZrP-CEX becomes positive. Hence, it hinders the access of the metal ions into the pores of NaZrP-CEX surface. With $\mathrm{pH} 5$ or higher, the hydrolysis of U(VI) ions will occur, hydrolyzed forms of uranyl ions such as $\mathrm{UO}_{2}(\mathrm{OH})^{+},\left(\mathrm{UO}_{2}\right)_{2}(\mathrm{OH})_{2}{ }^{2+}$ and $\left(\mathrm{UO}_{2}\right)_{3}(\mathrm{OH})_{5}{ }^{+}$ are dominant $[3,13]$. Therefore, the observed decrease in the uptake of $\mathrm{UO}_{2}{ }^{2+}$ at $\mathrm{pH} \geq 6$ can be explained on the basis of the formation of those hydrolyzed species with lower adsorption affinities onto NaZrP-CEX ion-exchanger. The NaZrP-CEX cation-exchanger achieved their maximum amount adsorbed at $\mathrm{pH}$ 4.5. It should be noted that the experiments were not conducted beyond $\mathrm{pH} 6$ to avoid precipitation of $\mathrm{U}(\mathrm{VI})$ ions, in which the hydrolysis is more intense and anionic species such as $\left(\mathrm{UO}_{2}\right)_{3}(\mathrm{OH})_{7}{ }^{-}, \mathrm{UO}_{2}(\mathrm{OH})_{3}{ }^{-}$or the precipitation of $\mathrm{UO}_{2}(\mathrm{OH})_{2}$ are formed because of the excess of $\mathrm{OH}^{-}$in the solution. Additionally, the surface charge of NaZrP-CEX ion-exchanger became negative under alkaline conditions. The higher adsorption capacity for $\mathrm{UO}_{2}{ }^{2+}$ is attributed to the surface negative charge of $\mathrm{NaZrP}-\mathrm{CEX}$ over the whole $\mathrm{pH}$ range. As shown in Figure $4 \mathrm{~b}$, the negative value of zeta potential indicates that a large amount of negative charge covers the surface of the NaZrP-CEX, favoring the adsorption of $\mathrm{UO}_{2}{ }^{2+}$. Further, the maximum adsorption capacity of $\mathrm{UO}_{2}{ }^{2+}$ was found at $\mathrm{pH}$ 4.5. Therefore, the adsorption of uranyl ions on sodium zirconium phosphate (NaZrP) should be on the basis of a simple ion-exchange mechanism and the mesostructured features, actively inner/outer surface pore and framework of NaZrP. Once, the mesoporous NaZrP contact with the uranyl ions in solution, the hydrogen/sodium ions (active sites) replaced by $\mathrm{U}$ ions based on $\mathrm{pH}$ values (nZrP-ONa + $\left.\mathrm{UO}^{2+} \rightarrow(\mathrm{ZrP}-\mathrm{O})_{\mathrm{n}}-\mathrm{UO}^{+2}+\mathrm{nNa}^{+}\right)[40]$. 

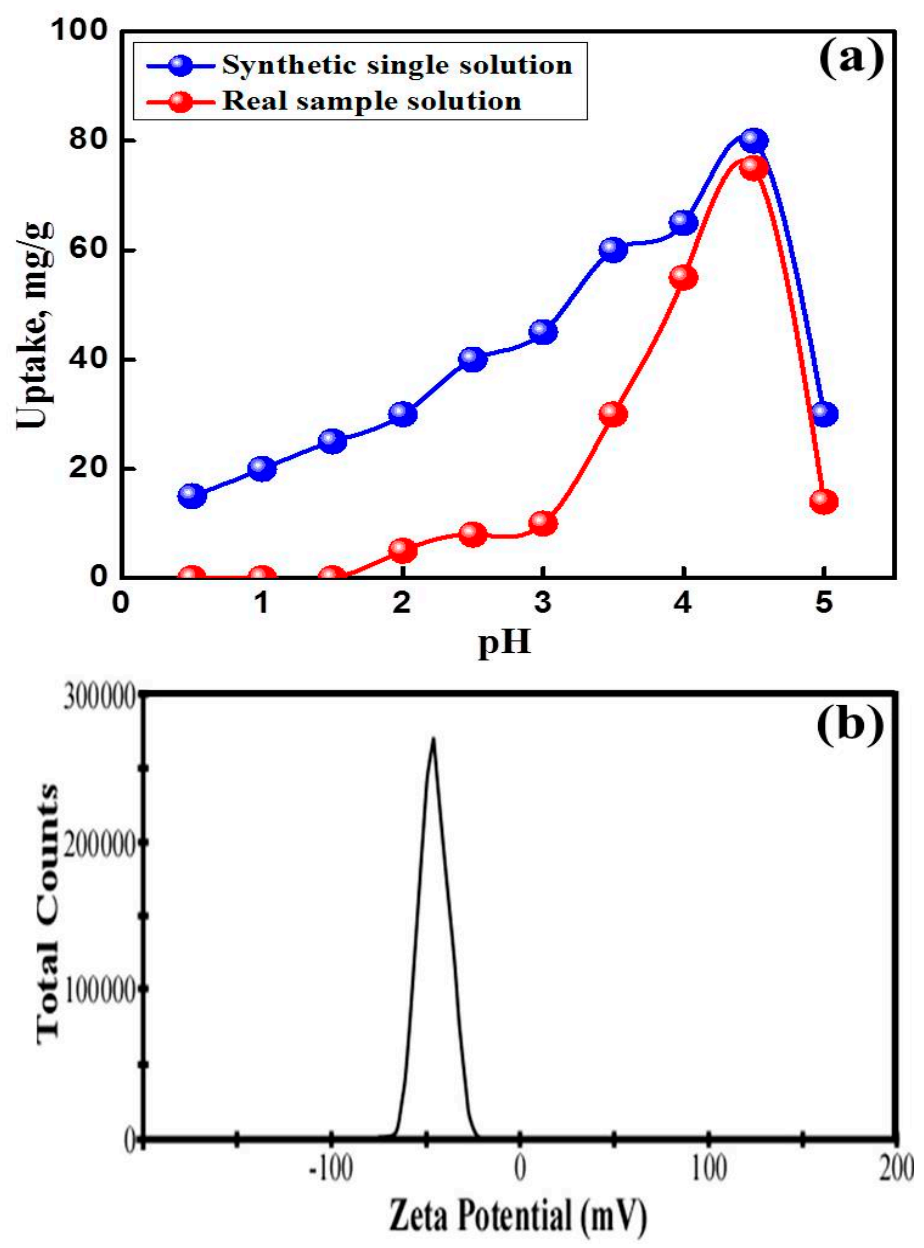

Figure 4. (a) Effect of initial $\mathrm{pH}$ on the adsorption of uranyl ions on NaZrP-CEX in single solution (initial uranyl concentration $100 \mathrm{mg} \mathrm{L}^{-1}$, NaZrP-CEX weight $20 \mathrm{mg}$, solution volume $20 \mathrm{~mL}$, contact time $3 \mathrm{~h}$ and $25{ }^{\circ} \mathrm{C}$ ) and real sample solution containing uranium ions. (b) Zeta potential of the mesoporous NaZrP particles.

\subsubsection{Effect of the Adsorbent Dose}

The effect of NaZrP-CEX cation-exchanger dose on the adsorption of uranyl ions was studied at an ambient temperature of $25^{\circ} \mathrm{C}$ with contact time of $3 \mathrm{~h}$. As shown in Figure 5, it was observed that the recovery percentage of uranyl increases with increasing the ZrP-CEX dose. Mesoporous ZrP-CEX could remove nearly $97.5 \%$ of uranyl with a dose of $4.0 \mathrm{~g} \mathrm{~L}^{-1}$, which could be attributed to the availability of surface area and hence adsorption sites. The adsorbent dose significantly influenced the removal efficiency (\%) of uranyl ion from aqueous solution at $\mathrm{pH}=4.5$. The amount removed from solution was greatly increase from $26.0 \%$ (by $10 \mathrm{mg}$ ) to $97.5 \%$ (by $80 \mathrm{mg}$ ) of NaZrP-CEX cation-exchanger. However, the adsorption efficiency varied slightly at NaZrP-CEX dose greater than $80 \mathrm{mg}$ giving value of $98 \%$ by $100 \mathrm{mg}$ of NaZrP-CEX cation-exchanger. At low NaZrP-CEX cation-exchanger dose, all types of sites are entirely exposed and the adsorption on the surface is saturated faster, giving a greater $\mathrm{q}_{\mathrm{e}}$ value at equilibrium. Moreover, the binding ability of NaZrP-CEX towards uranyl ions can be explained by means of the adsorption distribution coefficient $\left(K_{\mathrm{d}}, \mathrm{L} / \mathrm{g}\right)$ calculated as $\left(\mathrm{K}_{\mathrm{d}}=C_{s} / C_{L}\right)$ [41]. The term $C_{S}$ is the $\mathrm{UO}_{2}{ }^{2+}$ ions concentration adsorbed on the mesoporous NaZrP-CEX particles $(\mathrm{mg} / \mathrm{g})$ and $C_{L}$ is the concentration of $\mathrm{UO}_{2}{ }^{2+}$ ions in aqueous solution $(\mathrm{mg} / \mathrm{L})$. Figure 5 shows that the $\mathrm{K}_{\mathrm{d}}$ increases with increasing the adsorbent dose, which indicates heterogeneity of the adsorbent surface. In the case of a homogeneous surface, the $K_{d}$ values are kept the same with increasing the adsorbent concentrations at the optimal $\mathrm{pH}$ value. 


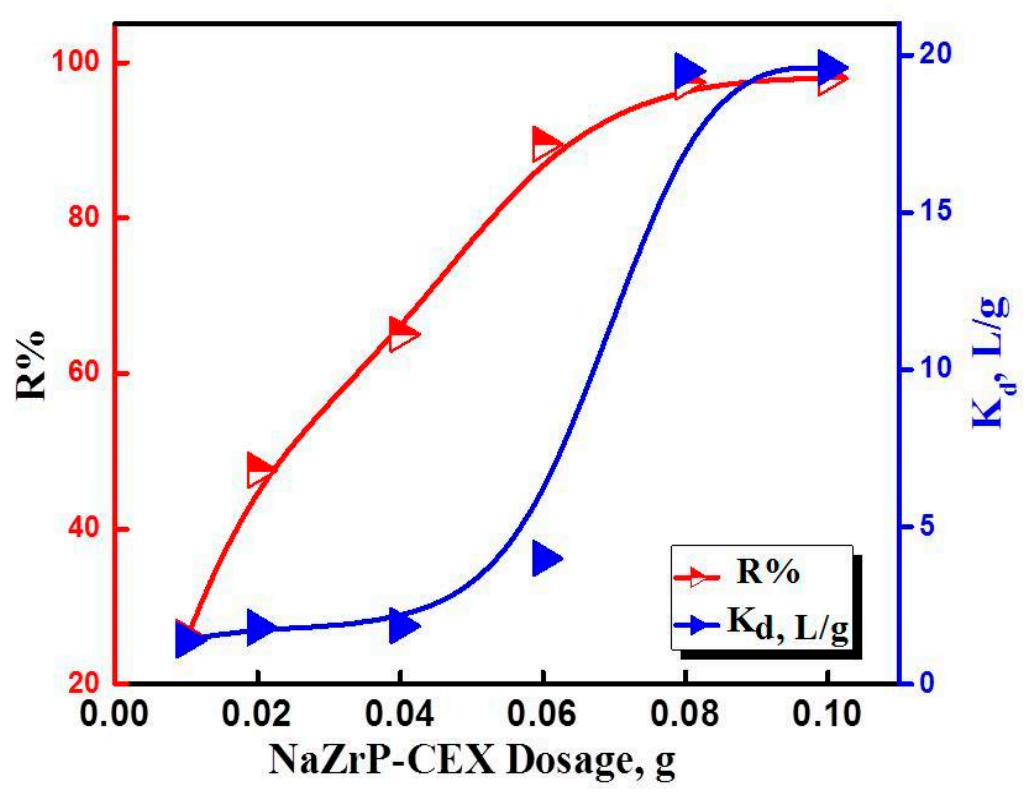

Figure 5. Effect of NaZrP-CEX doses and distribution coefficient $\left(\mathrm{K}_{\mathrm{d}}\right)$ for $\mathrm{UO}_{2}{ }^{2+}$ adsorption onto NaZrP-CEX cation-exchanger.

\subsubsection{Effect of Contact Time}

The variation of contact time is one of the most important parameter in determining the adsorption potential of an adsorbent. Adsorption of uranyl ions on NaZrP-CEX was studied within a time period of $1-200 \mathrm{~min}$ at $25{ }^{\circ} \mathrm{C}$ and $\mathrm{pH} 4.5$. Within $30 \mathrm{~min}$, the uptake of uranyl ions represents $43.75 \%$ from the uptake capacity at the plateau and the equilibrium was attained within $180 \mathrm{~min}$ from a synthetic water sample containing $100 \mathrm{mg} \mathrm{L}^{-1}$ of uranyl ions. In an attempt to describe the adsorption kinetics, the adsorption/time data of Figure 6a was fitted with pseudo-second-order model. In this model, all the steps of adsorption including external diffusion, internal diffusion, and adsorption are lumped together in Equation (3) [42]:

$$
\frac{t}{q_{t}}=\frac{t}{q_{e}}+\frac{1}{k_{2} q_{e}^{2}}
$$

where $k_{2}$ is the overall pseudo-second-order rate constant $(\mathrm{g} / \mathrm{mg} \mathrm{min})$. Plotting of $\mathrm{t} / \mathrm{q}_{\mathrm{t}}$ versus $\mathrm{t}$ shown in Figure $6 \mathrm{~b}$ gave a straight line with a slope and an intercept from which the $\mathrm{q}_{\mathrm{e}}$ and $\mathrm{k}_{2}$ were calculated. Obviously, a satisfactory agreement was obtained between calculated and experimental values of $\mathrm{q}_{\mathrm{e}}$. This implies that the adsorption process proceeds conveniently according to pseudo-second-order kinetics and depends on the concentration of both the surface active sites and uranyl ions. In order to show the effect of intraparticle diffusion on the rate of the adsorption, the adsorption/time data were treated according to intraparticle diffusion Equation (4) [13]:

$$
\mathrm{q}_{\mathrm{t}}=\mathrm{x}+\mathrm{k}_{\mathrm{i}} \mathrm{t}^{0.5}
$$

where $\mathrm{K}_{\mathrm{i}}\left(\mathrm{mmol} \mathrm{g} \mathrm{min}^{-0.5}\right)$ is the intraparticle diffusion rate constant, and $\mathrm{x}$ is the intercept which is proportional to the boundary layer thickness. As seen from Figure $6 c$, the plots are characterized by two main stages, where one of them passes through the origin and the other does not pass. This indicates that the rate of adsorption is affected by both intraparticle diffusion and boundary layer. 

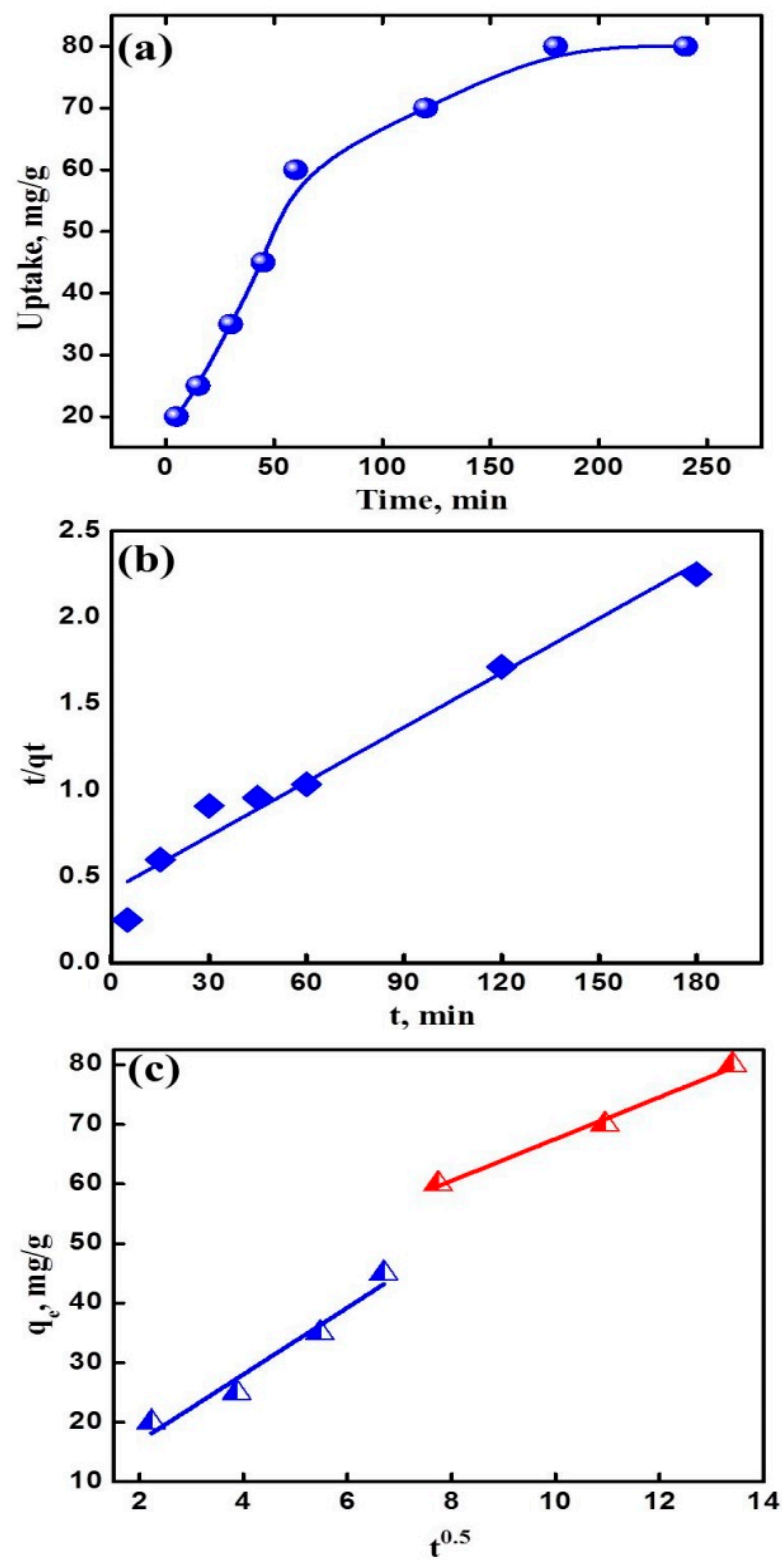

Figure 6. (a) Effect of contact time on the adsorption of uranyl ions on NaZrP-CEX from a single ion solution; $\mathrm{pH} 4.5$ initial uranyl ions concentration $100 \mathrm{mg} \mathrm{L}^{-1}$, NaZrP-CEX weight $20 \mathrm{mg}$, solution volume $20 \mathrm{~mL}$ at $25^{\circ} \mathrm{C}$. (b) The pseudo-second-order plot and (c) the intraparticle diffusion plot.

\subsubsection{Effect of Initial Concentration of Uranyl Ions}

The effect of initial concentrations of uranyl ions uptake was investigated by varying the initial concentrations $\mathrm{UO}_{2}{ }^{2+}$ at optimum $\mathrm{pH}$ value 4.5 for $3 \mathrm{~h}$ showing maximum uptake capacity of 129.6, 135 and $140.2 \mathrm{mg} / \mathrm{g}$ at 25,35 , and $45^{\circ} \mathrm{C}$, respectively (Figure 7a). In order to understand the adsorption capacity of the fabricated NaZrP-CEX, the adsorption capacity was evaluated according to different isotherms models like Langmuir and Freundlich models. The Langmuir isotherm assumes that adsorption occurs by homogeneous adsorption sites on the sorbent and the intermolecular forces decrease rapidly with increasing the distance from the adsorption surface. Langmuir model plotted in (Figure 7a) can be expressed in Equation (5) [43]:

$$
\frac{\mathrm{C}_{\mathrm{e}}}{\mathrm{q}_{\mathrm{e}}}=\frac{\mathrm{C}_{\mathrm{e}}}{\mathrm{Q}_{\max }}+\frac{1}{\mathrm{~K}_{\mathrm{L}} \mathrm{q}_{\max }},
$$


where $C_{e}$ is the equilibrium concentration of uranyl ions in solutions $(\mathrm{mg} / \mathrm{L}), \mathrm{q}_{\mathrm{e}}$ is the amount adsorbed on NaZrP-CEX at $\mathrm{C}_{\mathrm{e}}(\mathrm{mg} / \mathrm{g}), \mathrm{Q}_{\max }$ is the maximum adsorption capacity $(\mathrm{mg} / \mathrm{g})$, and $\mathrm{K}_{\mathrm{L}}$ is the binding constant of Langmuir which is related to the energy of adsorption $(\mathrm{L} / \mathrm{mg})$. The earliest known relationship describing the non-ideal and reversible adsorption is the Freundlich isotherm model, which can be applied to multilayer adsorption, on the basis of an assumption concerning the energetic surface heterogeneity. The Freundlich isotherm model plotted in (Figure 7c,d) is described by the nonlinear and linear equations and can be expressed in Equations (6) and (7) [44]:

$$
\begin{gathered}
\mathrm{q}_{\mathrm{e}}=\mathrm{k}_{\mathrm{F}} \mathrm{c}_{\mathrm{e}}^{1 / \mathrm{n}} \\
\log \mathrm{q}_{\mathrm{e}}=\log \mathrm{k}_{\mathrm{F}}+\frac{1}{\mathrm{n}} \log \mathrm{Ce},
\end{gathered}
$$

where $\mathrm{K}_{\mathrm{F}}$ and $\mathrm{n}$ are the Freundlich constants related to the adsorption capacity and intensity, respectively. The values of $\mathrm{K}_{\mathrm{L}}, \mathrm{Q}_{\max }, \mathrm{K}_{\mathrm{F}}$, and $\mathrm{n}$ were obtained. The maximum Langmuir adsorption capacities $\left(Q_{\max }\right)$ obtained were in good agreement with the experimental ones, and the values of $\mathrm{R}^{2}$, which is a measure of the goodness of fit, confirm the better representation of the experimental data by Langmuir model than Freundlich model. However, the Freundlich isotherm parameters obtained from the linear approach gave higher $\mathrm{R}^{2}$ values compared to the non-linear least-square approach. Moreover, when these models are compared, Freundlich isotherm models have a higher correlation of determination than Langmuir model as shown in Figure 7. This indicates the homogeneity of active sites on $\mathrm{ZrP}-\mathrm{CEX}$ surface. Calculations were carried out to determine the predicted amount of uranium as a function of the weight of NaZrP-CEX meso-sorbent for the actual $\mathrm{UO}_{2}{ }^{2+}$ ions concentrations present in solution. This indicates that the required NaZrP-CEX meso-sorbent weight for any range of concentrations could be theoretically pre-estimated prior to the actual adsorption process. The weight of NaZrP-CEX required to intake $\mathrm{UO}_{2}{ }^{2+}$ ions in a concentration ranged from 1 to $100 \mathrm{mg} / \mathrm{L}$ in one litter of the containing $\mathrm{UO}_{2}{ }^{2+}$ solution was calculated to be $0.825 \mathrm{~g} / \mathrm{L}$. The NaZrP-CEX exhibited substantial adsorption efficiency, which is comparable with that of previously prepared in organic adsorbents, such as oxides and phosphates compounds (Table 2) [45-54].

Table 2. Comparison of the adsorption capacities of U(VI) ions onto various inorganic absorbents.

\begin{tabular}{lcc}
\hline \multicolumn{1}{c}{ Adsorbent } & Uptake, $\mathbf{~ m g / g}$ & Ref. \\
\hline Zinc MOF carboxylate & 114.70 & {$[45]$} \\
MIL-68/GO & 375.00 & {$[46]$} \\
K+-Activated Robust Zeolitic Sulfide & 147.60 & {$[47]$} \\
Amino-functionalized palygorskite & 90.20 & {$[48]$} \\
Titanate nanotubes & 333.00 & {$[49]$} \\
Mg-Co layered-double-hydroxide & 915.61 & {$[50]$} \\
rGO/LDH & 277.80 & {$[51]$} \\
Hematite & 3.36 & {$[52]$} \\
Zr-Sb oxide/PAN & 60.66 & {$[53]$} \\
Manganese oxide coated zeolite & 15.10 & {$[54]$} \\
HAp & 59.30 & {$[13]$} \\
NaZrP-CEX & 129.60 & {$[$ This work] } \\
\hline
\end{tabular}



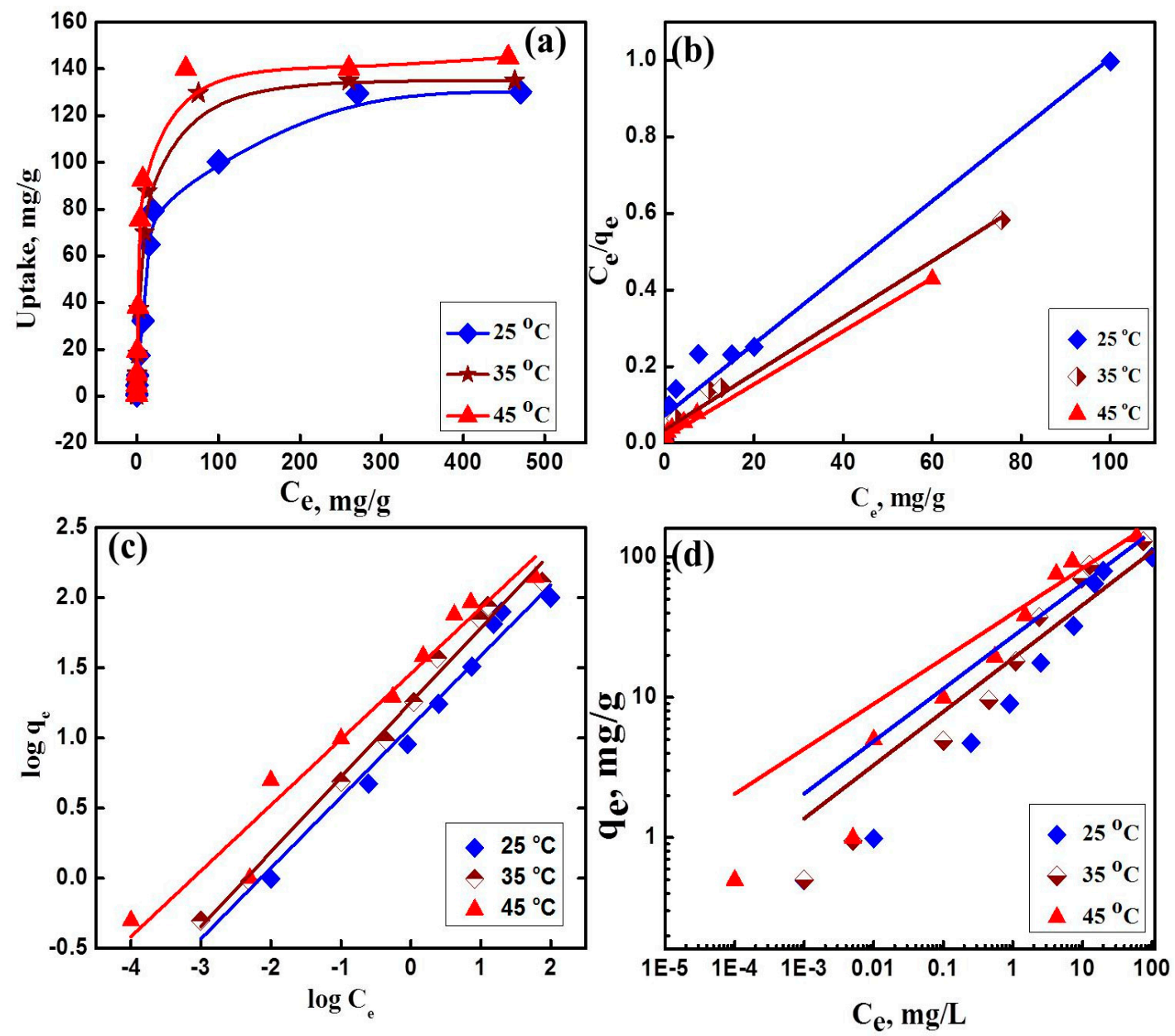

Figure 7. (a) Adsorption isotherm of uranyl ions adsorption on NaZrP-CEX from a single ion solution; $\mathrm{pH} 4.5, \mathrm{ZrP}-\mathrm{CEX}$ weight $20 \mathrm{mg}$, solution volume $20 \mathrm{~mL}$, contact time $2 \mathrm{~h}$ at different temperatures $\left(25,35\right.$ and $\left.45^{\circ} \mathrm{C}\right)$. (b) Langmuir plot, (c) linear Freundlich plot, and (d) nonlinear Freundlich plot of the adsorption of uranyl ions on NaZrP-CEX at different temperatures.

\subsection{Thermodynamics Studies of Uranyl Ions Adsorption on NaZrP-CEX}

Evaluation of the thermodynamic parameters is of considerable value in optimizing the process application, to show the feasibility of the adsorption of uranyl ions on NaZrP-CEX process. The thermodynamic parameters for the adsorption of $\mathrm{UO}_{2}{ }^{2+}$ ions onto NaZrP-CEX mesoporous adsorbent were calculated by substituting $\mathrm{K}_{\mathrm{L}}$ (obtained from equation 4 at different temperatures) into the Van't Hoff equation (Figure 8a) [55].

$$
\ln \mathrm{K}_{\mathrm{L}}=\frac{-\Delta \mathrm{H}^{\circ}}{\mathrm{RT}}+\frac{\Delta \mathrm{S}^{\circ}}{\mathrm{R}}
$$

The positive value of $\Delta \mathrm{H}^{\circ}(61.4 \mathrm{~kJ} / \mathrm{mol})$ indicates the endothermic nature of a chemical adsorption of $\mathrm{UO}_{2}{ }^{2+}$ onto the fabricated NaZrP-CEX meso-sorbent. The positive $\Delta \mathrm{S}^{\circ}$ value suggests the increase in the uranyl ions entropic concentration and randomness at the solid-liquid interface during adsorption. The Gibbs free energy of adsorption $\left(\Delta \mathrm{G}^{\circ}\right)$ was calculated using the Gibbs free energy (Equation (9)):

$$
\Delta \mathrm{G}^{\circ}=\Delta \mathrm{H}^{\circ}-\mathrm{T} \Delta \mathrm{S}^{\circ}
$$



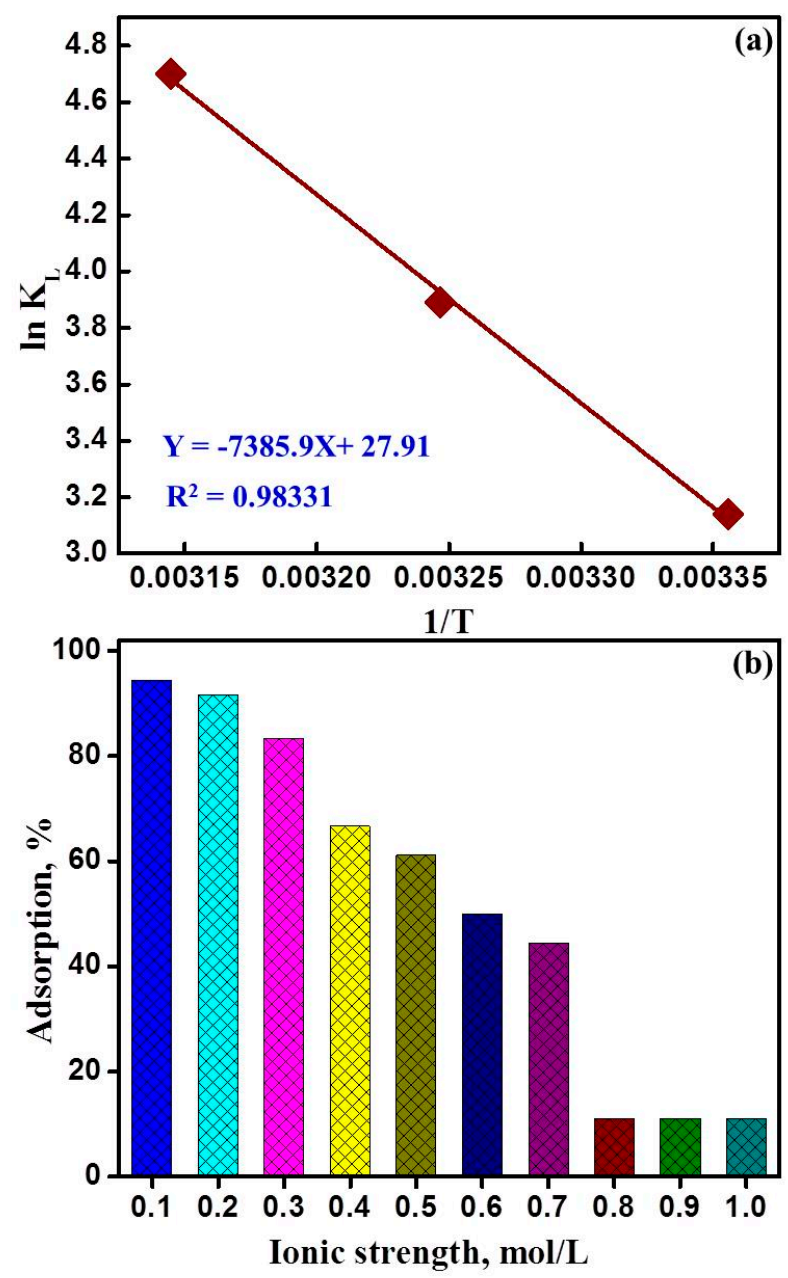

Figure 8. (a) Van't Hoff plot for the adsorption of uranyl ions on mesoporous NaZrP-CEX cation-exchanger and (b) Effect of ionic strength on the adsorption of uranyl ions on mesoporous NaZrP-CEX cation-exchanger.

The negative $\Delta G^{\circ}$ values confirm the spontaneous nature and feasibility of the adsorption process. The $\Delta \mathrm{G}^{\circ}$ values increase with increasing the temperatures from 25 to $45^{\circ} \mathrm{C}$ indicating the chemical adsorption nature of the adsorption. The values of $\Delta \mathrm{G}$ for the adsorption of $\mathrm{UO}_{2}{ }^{2+}$ ions on the fabricated mesoporous sorbent were listed in Table 3. The values of $\Delta G^{\circ}$ at different temperatures indicate that the adsorption of $\mathrm{UO}_{2}{ }^{2+}$ ions onto mesoporous NaZrP-CEX is a spontaneous process and become more favorable at higher temperatures. Moreover, the data show that $\left|\Delta \mathrm{H}^{\circ}\right|<\left|-\mathrm{T} \Delta \mathrm{S}^{\circ}\right|$, implying that the adsorption reaction is dominated by entropic rather than enthalpic changes.

Table 3. Freundlich, Langmuir parameters for the adsorption of the uranyl ions into the fabricated $\mathrm{NaZrP-CEX}$ ion-exchanger at different temperatures.

\begin{tabular}{|c|c|c|c|c|c|c|c|c|c|c|c|c|c|}
\hline \multirow[t]{2}{*}{$\mathrm{T}, \mathrm{k}$} & \multirow[t]{2}{*}{$\begin{array}{c}\mathrm{q}_{\mathrm{e}} . \\
\mathrm{mg} / \mathrm{g}\end{array}$} & \multicolumn{3}{|c|}{$\begin{array}{l}\text { Non-Linear } \\
\text { Freundlich } \\
\text { Parameters }\end{array}$} & \multicolumn{3}{|c|}{$\begin{array}{l}\text { Linear Freundlich } \\
\text { Parameters }\end{array}$} & \multicolumn{3}{|c|}{$\begin{array}{l}\text { Langmuir } \\
\text { Parameters }\end{array}$} & \multicolumn{3}{|c|}{$\begin{array}{c}\text { Thermodynamic } \\
\text { Parameters }\end{array}$} \\
\hline & & $K_{F}$ & $\mathbf{n}$ & $\mathrm{R}^{2}$ & $\mathbf{K}_{\mathrm{F}}$ & $\mathbf{n}$ & $\mathbf{R}^{2}$ & $Q_{\max }$ & $\mathrm{K}_{\mathrm{L}}$ & $\mathbf{R}^{2}$ & $\Delta \mathbf{H}^{\circ}$ & $\Delta \mathbf{S}^{\circ}$ & $\Delta \mathrm{G}^{\circ}$ \\
\hline 298 & 129.6 & 39.6 & 3.10 & 0.946 & 12.0 & 1.98 & 0.979 & 107.5 & 0.18 & 0.968 & & & -7.7 \\
\hline 308 & 135.2 & 18.9 & 2.63 & 0.907 & 17.8 & 1.87 & 0.988 & 136.9 & 0.21 & 0.982 & 61.4 & 0.23 & -10.1 \\
\hline 318 & 140.3 & 27.2 & 2.67 & 0.955 & 28.8 & 2.13 & 0.954 & 144.9 & 0.46 & 0.991 & & & -12.4 \\
\hline
\end{tabular}




\subsection{NaZrP-CEX Regeneration}

For economical extraction of metal ions, the utilized materials should exhibit high reproducibility, high performance, recyclability, and durability. The effective elution of the mesoporous-NaZrP-CEX cation exchanger was found feasible using $\mathrm{HNO}_{3}(0.05 \mathrm{M})$ or $\mathrm{HCl}(1 \mathrm{M})$. The mesoporous-NaZrP-CEX was maintained up to the seven cycles of regeneration and reuse, after which a subtle decrease in efficiency was observed as illustrated in Figure 8b. This small change in the NaZrP-CEX efficiency most likely arises from the treatment with the stripping agents during the recycling processes. The sensitivity, specificity, and reusability of the mesoporous-NaZrP-CEX cation exchanger, together with its ease of use, give it potential not only in uranium remediation but also in the extraction of uranium from its natural ores.

\subsection{Applicability Evaluation}

The sample under study was selected from the middle member of the uraniferous Um-Bogma formation and composed of ferruginous mudstone (i.e., Gebel Um-Hamd is located in Southwestern of Sinai, south Wadi El Sahu, Egypt [56]. It extends along E-W trend and has an altitude of about $850 \mathrm{~m}$ ). XRD data (Figure 9) of the bulk sample revealed that it consist of clay minerals, quartz, hematite and carnotite $\left(\mathrm{KUO}_{2} \mathrm{VO}_{4}\right)$ was recorded as the main radioactive mineral. In addition to carnotite, it contains traces of zircon, monazite, fergusonite, xenotime and columbite. This ore contains $951 \mathrm{mgL}^{-1} \mathrm{U}$, $559 \mathrm{mgL}^{-1} \mathrm{Cu}, 1398 \mathrm{mgL}^{-1} \mathrm{Zn}$, and contain $13.31 \% \mathrm{Fe}_{2} \mathrm{O}_{3}(\mathrm{~T})$ and $0.04 \% \mathrm{MnO}$. The hydrometallurgical process here is based on one leaching step, in $\mathrm{HNO}_{3}$ followed by adsorption process, to mainly extract uranium ions. A $100 \mathrm{~g}$ of ore under study was grinded then treated with $30 \mathrm{~g} / \mathrm{L}$ nitric acid 1:3 $\mathrm{S} / \mathrm{L}$ ratio for $3 \mathrm{~h}$ followed with filtration for removal of undissolved materials. The residue was washed with $5 \mathrm{~g} / \mathrm{L}$ nitric acid $1: 2 \mathrm{~S} / \mathrm{L}$ ratio and the obtained liquor was $300 \mathrm{~mL}(\mathrm{pH} 0.6)$ contained $235 \mathrm{mgL}^{-1} \mathrm{U}$, $15.2 \mathrm{mgL}^{-1} \mathrm{Cu}, 43.6 \mathrm{mgL}^{-1} \mathrm{Zn}, 52.8 \mathrm{mgL}^{-1} \mathrm{Fe}$ and $18 \mathrm{mgL}^{-1} \mathrm{Mn}$. After adjusting the $\mathrm{pH}$ at 4.1 to remove iron ions, the total concentrations of metal ions is decreased to be $180 \mathrm{mgL}^{-1} \mathrm{U}, 13.6 \mathrm{mgL}^{-1} \mathrm{Cu}$, $16 \mathrm{mgL}^{-1} \mathrm{Zn}, 0.3 \mathrm{mgL}^{-1} \mathrm{Fe}$ and $17.6 \mathrm{mgL}^{-1} \mathrm{Mn}$.

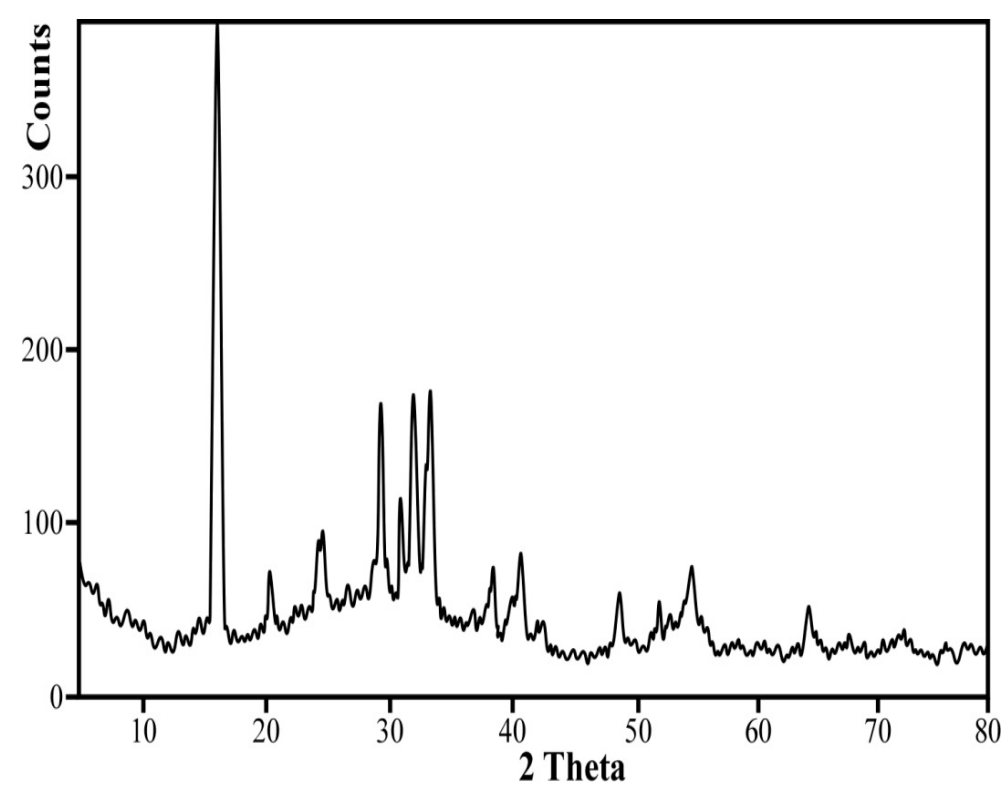

Figure 9. XRD of the bulk sample of Um Hamd ore.

The second stage is the extraction of uranium ions from the pregnant leach solution containing $\mathrm{U}, \mathrm{Fe}, \mathrm{Cu}$, and $\mathrm{Al}$, and $\mathrm{Fe}$. A series of batch experiments were performed to define and evaluate the specific extraction of uranyl ions from a diluted real sample (300 ppm U(VI)) after adjusting the $\mathrm{pH}$ at 6. The uranyl ions extraction assays were performed under optimal conditions (i.e., $\mathrm{pH} 4.5,100 \mathrm{mg}$ of 
NaZrP-CEX, $50 \mathrm{~mL}$ volume, $3 \mathrm{~h}$ of stirring at $400 \mathrm{rpm}$, temperature of $25^{\circ} \mathrm{C}$. After removal, the filtrate was analyzed using ICP. The uptake percentage of uranyl ions using the NaZrP-CEX was obtained up to $90 \%$ in the presence of high concentrations of competing ions at different $\mathrm{pHs}$ (Figure 4a). Furthermore, the extraction experiment using a stripping agent was conducted through a liquid-exchange process to release the uranyl ions and obtain $\mathrm{U}(\mathrm{VI})$ metal ion-free sorbent surfaces. The ICP analysis of the collected uranyl ions solution also indicates that approximately $98 \%$ of $\mathrm{U}(\mathrm{VI})$ metal ions were released using $\mathrm{HCl}(0.1 \mathrm{M})$ or $\mathrm{HNO}_{3}(0.05 \mathrm{M})$. This result indicates that NaZrP-CEX is highly selective to uranium ions even in the presence of high concentrations of competing ions. The NaZrP-CEX achieves high-performance collection, recovery, and extraction of uranyl ions. Therefore, it is highly applicable in the mining processing, which is primary a source of economic metal ions.

\section{Conclusions}

In this study, we described the design and engineering of self-functionalized mesoporous NaZrP-CEX nanoparticles based on the tailored channel arrays of warm-like meso-pores of zirconium phosphate. The fabricated meso-sorbent exhibited large surface area and large pore sizes for easy trapping uranyl ions from aqueous solutions. The solution $\mathrm{pH}$ exhibited an important functionality of uranyl ions adsorption on self-functionalized NaZrP-CEX with an optimum $\mathrm{pH}$ at 4.5. The adsorption isotherm was well fitted by Langmiur and Freundlich isotherm models and the calculated maximum adsorption capacity was $129.6 \mathrm{mg} \mathrm{g}^{-1}$ at $25{ }^{\circ} \mathrm{C}$. Moreover, the capture-and-release process of the $\mathrm{NaZrP}-\mathrm{CEX}$ for uranyl ions has an efficiency of up to $92.3 \%$ in real samples. These data indicate that this ion-capture model allows the development of a simple and effective technique for effective extraction of uranium from its leach liquor.

Author Contributions: Conceptualization, E.A.E., M.S.A., M.E.E.-K., Y.K.A.-M and I.G.A.; writing-original draft preparation, I.G.A. and E.A.E.; writing-review and editing, M.E.E.-K. and Y.K.A.-M.; visualization, M.E.E.-K. and E.A.E.; supervision, Y.K.A.-M. and M.S.A.

Funding: This research received no external funding.

Conflicts of Interest: The authors declare no conflict of interests.

\section{References}

1. Uranium Resources, production and demand, OECD NEA Publication 6891, 2010.

2. Edwards, C.R.; Oliver, A.J. Uranium processing: A review of current methods and technology. JOM 2000, 52, 12-20. [CrossRef]

3. Elshehy, E.A. Removal of uranium ions from liquid radioactive waste using modified aluminosilica. Sep. Sci. Technol. 2017, 52, 1852-1861. [CrossRef]

4. Seko, N.; Katakai, A.; Hasegawa, S.; Tamada, M.; Kasai, N.; Takeda, H.; Sugo, T.; Saito, K. Aquaculture of Uranium in Seawater by a Fabric-Adsorbent Submerged System. Nucl. Technol. 2003, 144, $274-278$. [CrossRef]

5. Kuznetsov, V.; Zemyatova, S.; Kornev, K. Automated determination of uranium(VI) in seawater using on-line preconcentration by coprecipitation. J. Anal. Chem. 2017, 69, 105-110. [CrossRef]

6. Schneider, E.; Lindner, H. Energy Balance of Uranium Recovery from Seawater. In Proceedings of GLOBAL 2013: Nuclear Energy at a Crossroads; American Nuclear Society: La Grange Park, IL, USA, 2013.

7. Schnug, E.; Lottermoser, B.G. Fertilizer-Derived Uranium and its Threat to Human Health. Environ. Sci. Technol. 2013, 47, 2433-2434. [CrossRef] [PubMed]

8. Hore-Lacy, I. Uranium for Nuclear Power, Resources. In Mining and Transformation to Fuel, 1st ed.; Woodhead Publishing: Cambridge, UK, 2016.

9. Wahab, S.A.; Rezik, A.; Abu Khoziem, H.A.; Khalid, E.; Abdellah, W. Kinetics of uranium carbonate leaching process from carbonaceous shale, southwestern Sinai, Egypt. Euro-Mediterr. J. Environ. Integr. 2019, 4, 19. [CrossRef] 
10. James, D.; Venkateswaran, G.; Rao, T.P. Removal of uranium from mining industry feed simulant solutions using trapped amidoxime functionality within a mesoporous imprinted polymer material. Microporous Mesoporous Mater. 2009, 119, 165-170. [CrossRef]

11. Atia, B.M.; Gado, M.A.; Cheira, M.F. Kinetics of uranium and iron dissolution by sulfuric acid from Abu Zeneima ferruginous siltstone, Southwestern Sinai, Egypt. Euro-Mediterr. J. Environ. Integr. 2018, 3, 39. [CrossRef]

12. Zhu, Z.; Pranolo, Y.; Cheng, C.Y. Uranium recovery from strong acidic solutions by solvent extraction with Cyanex 923 and a modifier. Miner. Eng. 2016, 89, 77-83. [CrossRef]

13. El-Din, A.F.T.; Elshehy, E.A.; El-Khouly, M.E. Cellulose acetate/EDTA-chelator assisted synthesis of ordered mesoporous HAp microspheres for efficient removal of radioactive species from seawater. J. Environ. Chem. Eng. 2018, 6, 5845-5854. [CrossRef]

14. Alqadami, A.A.; Naushad, M.; Alothman, Z.A.; Ghfar, A.A. Novel Metal-Organic Framework (MOF) Based Composite Material for the Sequestration of U(VI) and Th(IV) Metal Ions from Aqueous Environment. ACS Appl. Mater. Interfaces 2017, 9, 36026-36037. [CrossRef] [PubMed]

15. Pugazhendhi, A.; Boovaragamoorthy, G.M.; Ranganathan, K.; Naushad, M.; Kaliannan, T. New insight into effective biosorption of lead from aqueous solution using Ralstonia solanacearum: Characterization and mechanism studies. J. Clean. Prod. 2018, 174, 1234-1239. [CrossRef]

16. Naushad, M.; ALOthman, Z.A. Separation of toxic $\mathrm{Pb}^{2+}$ metal from aqueous solution using strongly acidic cation-exchange resin: Analytical applications for the removal of metal ions from pharmaceutical formulation, Desalin. Water Treat. 2015, 53, 2158-2166. [CrossRef]

17. Naushad, M. Surfactant assisted nano-composite cation exchanger: Development, characterization and applications for the removal of toxic $\mathrm{Pb}^{2+}$ from aqueous medium. Chem. Eng. J. 2014, 235, 100-108. [CrossRef]

18. Shenashen, M.; Elshehy, E.A.; El-Safty, S.; Khairy, M. Visual monitoring and removal of divalent copper, cadmium, and mercury ions from water by using mesoporous cubic Ia3d aluminosilica sensors. Sep. Purif. Technol. 2013, 116, 73-86. [CrossRef]

19. Shenashen, M.; El-Safty, S.; Elshehy, E.; Shenashen, M. Architecture of optical sensor for recognition of multiple toxic metal ions from water. J. Hazard. Mater. 2013, 260, 833-843. [CrossRef] [PubMed]

20. Tranter, T.J.; Herbst, R.S.; Todd, T.A. Evaluation of ammonium molybdophosphate-polyacrylonitrile AMP-PAN as a cesium selective sorbent for the removal of 137Cs from acidic nuclear waste solutions. Adv. Environ. Res. 2002, 6, 107-121. [CrossRef]

21. Seaton, K.; Little, I.; Tate, C.; Mohseni, R.; Roginskaya, M.; Povazhniy, V.; Vasiliev, A.; Little, I. Adsorption of cesium on silica gel containing embedded phosphotungstic acid. Microporous Mesoporous Mater. 2017, 244, 55-66. [CrossRef]

22. Tag El-Dina, A.; Elshehy, E.A.; El-Khouly, M.E.; Atia, A. Cellulose Acetate Assisted Synthesis of Worm-Shaped Mesoporous MgP Ion-Exchanger for Cesium Ions Removal from Seawater. Microporous Mesoporous Mater. 2018, 265, 211-218. [CrossRef]

23. Naushad, M.; Ahamad, T.; Al-Maswari, B.M.; Alqadami, A.A.; AlShehri, S.M. Nickel ferrite bearing nitrogen-doped mesoporous carbon as efficient adsorbent for the removal of highly toxic metal ion from aqueous medium. Chem. Eng. J. 2017, 330, 1351-1360. [CrossRef]

24. Sharma, G.; Pathania, D.; Naushad, M.; Kothiyal, N.C. Fabrication, characterization and antimicrobial activity of polyaniline $\mathrm{Th}(\mathrm{IV})$ tungstomolybdophosphate nanocomposite material: Efficient removal of toxic metal ions from water. Chem. Eng. J. 2014, 251, 413-421. [CrossRef]

25. Mironyuk, I.; Tatarchuk, T.; Naushad, M.; Vasylyeva, H.; Mykytyn, I. Highly efficient adsorption of strontium ions by carbonated mesoporous $\mathrm{TiO}_{2}$. J. Mol. Liq. 2019, 285, 742-753. [CrossRef]

26. Chakraborty, R.; Chatterjee, S.; Chattopadhyay, P. Radioanalytical separation and size-dependent ion exchange property of micelle-directed titanium phosphate nanocomposites. J. Radioanal. Nucl. Chem. 2014, 299, 1565-1570. [CrossRef]

27. Itoh, K.; Nakayama, S. Immobilization of cesium by crystalline zirconium phosphate. J. Mater. Sci. 2002, 37, 1701-1704. [CrossRef]

28. Swain, S.; Patnaik, T.; Singh, V.; Jha, U.; Patel, R.; Dey, R.; Patel, R. Kinetics, equilibrium and thermodynamic aspects of removal of fluoride from drinking water using meso-structured zirconium phosphate. Chem. Eng. J. 2011, 171, 1218-1226. [CrossRef] 
29. Chakraborty, R.; Bhattacharaya, K.; Chattopadhyay, P. Nanostructured zirconium phosphate as ion exchanger: Synthesis, size dependent property and analytical application in radiochemical separation. Appl. Radiat. Isot. 2014, 85, 34-38. [CrossRef] [PubMed]

30. Ananthanarayanan, A.; Ambashta, R.; Sudarsan, V.; Ajithkumar, T.; Sen, D.; Mazumder, S.; Wattal, P. Structure and short time degradation studies of sodium zirconium phosphate ceramics loaded with simulated fast breeder (FBR) waste. J. Nucl. Mater. 2017, 487, 5-12. [CrossRef]

31. Wang, Y.-Q.; Liu, Z.-J.; Guo, M.-L. Hydrothermal synthesized microflower sodium zirconium phosphate and its transformation to zirconium hydrogen phosphate. Mater. Lett. 2015, 159, 197-199.

32. Pet'Kov, V.I.; Sukhanov, M.V. Immobilisation of molybdenum from fuel reprocessing wastes into sodium zirconium phosphate ceramics. Czechoslov. J. Phys. 2003, 53, A671-A677. [CrossRef]

33. Donia, A.M.; Atia, A.A.; Daher, A.M.; Elshehy, E.A. Extraction and Separation of Zirconium(IV) and Hafnium(IV) from Chloride Media Using Magnetic Resin with Phosphoric Acid Functionality. J. Dispers. Sci. Technol. 2011, 32, 193-202. [CrossRef]

34. Yang, Y.; Dai, G.; Tan, S.; Liu, Y.; Shi, Q.; Ouyang, Y. Structure and synergetic antibacterial effect of zinc and cerium carried sodium zirconium phosphates. J. Rare Earth 2011, 29, 308-312. [CrossRef]

35. Wong, R.J.-H. Acid Zirconium Phosphate and Alkaline Hydrous Zirconium Oxide Materials for Sorbent Dialysis. US20100078387A1, 1 April 2010.

36. Cai, X.; Zhang, B.; Liang, Y.; Zhang, J.; Yan, Y.; Chen, X.; Wu, Z.; Liu, H.; Wen, S.; Tan, S.; et al. Study on the antibacterial mechanism of copper ion- and neodymium ion-modified $\alpha$-zirconium phosphate with better antibacterial activity and lower cytotoxicity. Colloids Surf. B Biointerfaces 2015, 132, 281-289. [CrossRef] [PubMed]

37. Sukhanov, M.V.; Ermilova, M.M.; Orekhova, N.V.; Pet'Kov, V.I.; Tereshchenko, G.F. Catalytic properties of zirconium phosphate and double phosphates of zirconium and alkali metals with a NaZr2(PO4)3 structure. Russ. J. Appl. Chem. 2006, 79, 614-618. [CrossRef]

38. Pet'Kov, V.I.; Sukhanov, M.V.; Ermilova, M.M.; Orekhova, N.V.; Tereshchenko, G.F. Development and synthesis of bulk and membrane catalysts based on framework phosphates and molybdates. Russ. J. Appl. Chem. 2010, 83, 1731-1741. [CrossRef]

39. Hong, C.; Ravindranathan, P.; Agrawal, D.K.; ROY, R. Synthesis of $\mathrm{NaZr}_{2} \mathrm{P}_{3} \mathrm{O}_{12}$ powders by evaporative decomposition of solutions. J. Mater. Sci. Lett. 1994, 13, 1015-1016.

40. Zakutevskyy, O.I.; Psareva, T.S.; Strelko, V.V. Sorption of U(VI) Ions on Sol-Gel-Synthesized Amorphous Spherically Granulated Titanium Phosphates. Russ J. Appl. Chem. 2012, 85, 1366-1370. [CrossRef]

41. Donat, R.; Akdogan, A.; Erdem, E.; Cetisli, H. Thermodynamics of $\mathrm{Pb}^{2+}$ and $\mathrm{Ni}^{2+}$ adsorption onto natural bentonite from aqueous solutions. J. Colloid Interface Sci. 2005, 286, 43-52. [CrossRef] [PubMed]

42. Weber, W.J.; Morris, J.C. Kinetics of adsorption on carbon from solutions. J. Sanit. Eng. Div. Am. Soc. Civ. Eng. 1963, 89, 31-60.

43. Langmuir, I. The adsorption of gases on plane surfaces of glass, mica and platinum. J. Am. Chem. Soc. 1918, 40, 1361-1401. [CrossRef]

44. Freundlich, H.M.F. Uber die adsorption in losungen. Z. Phys. Chem. 1906, 57, 385-470. [CrossRef]

45. Liu, R.; Wang, Z.-Q.; Liu, Q.-Y.; Luo, F.; Wang, Y.-L. A Zinc MOF with Carboxylate Oxygen-Functionalized Pore Channels for Uranium(VI) Sorption. Eur. J. Inorg. Chem. 2019, 2019, 735-739. [CrossRef]

46. Zhu, J.; Zhang, H.; Liu, Q.; Wang, C.; Sun, Z.; Li, R.; Liu, P.; Zhang, M.; Wang, J. Metal-organic frameworks (MIL-68) decorated graphene oxide for highly efficient enrichment of uranium. J. Taiwan Inst. Chem. E. 2019, 99, 45-52.

47. Sun, H.-Y.; Li, J.; Li, L.-Z.; Deng, Y.-L.; Liu, S.-H.; Feng, M.-L.; Huang, X.-Y. Fast and Selective Removal of Aqueous Uranium by a $\mathrm{K}^{+}$-Activated Robust Zeolitic Sulfide with Wide pH Resistance. Inorg. Chem. 2019, 58, 11622-11629.

48. Tobilko, V.; Spasonova, L.; Kovalchuk, I.; Kornilovych, B.; Kholodko, Y. Adsorption of Uranium (VI) from Aqueous Solutions by Amino-functionalized Clay Minerals. Colloids Interfaces 2019, 3, 41. [CrossRef]

49. Liu, W.; Zhao, X.; Wang, T.; Zhao, D.; Ni, J. Adsorption of U(VI) by multilayer titanate nanotubes: Effects of inorganic cations, carbonate and natural organic matter. Chem. Eng. J. 2016, 286, 427-435. [CrossRef]

50. Li, R.; Che, R.; Liu, Q.; Su, S.; Li, Z.; Zhang, H.; Liu, J.; Liu, L.; Wang, J. Hierarchically structured layered-double-hydroxides derived by ZIF-67 for uranium recovery from simulated seawater. J. Hazard. Mater. 2017, 338, 167-176. [CrossRef] [PubMed] 
51. Tan, L.; Wang, Y.; Liu, Q.; Wang, J.; Jing, X.; Liu, L.; Liu, J.; Song, D. Enhanced adsorption of uranium (VI) using a three-dimensional layered double hydroxide/graphene hybrid material. Chem. Eng. J. 2015, 259, 752-760. [CrossRef]

52. Xie, S.; Zhang, C.; Zhou, X.; Yang, J.; Zhang, X.; Wang, J. Removal of uranium (VI) from aqueous solution by adsorption of hematite. J. Environ. Radioact. 2009, 100, 162-166. [CrossRef]

53. Cakir, P.; İnan, S.; Altas, Y. Investigation of strontium and uranium sorption onto zirconium-antimony oxide/polyacrylonitrile ( $\mathrm{Zr}-\mathrm{Sb}$ oxide/PAN) composite using experimental design. J. Hazard. Mater. 2014, 271, 108-119. [CrossRef]

54. Han, R.; Zou, W.; Wang, Y.; Zhu, L. Removal of uranium(VI) from aqueous solutions by manganese oxide coated zeolite: Discussion of adsorption isotherms and pH effect. J. Environ. Radioact. 2007, 93, 127-143. [CrossRef]

55. Abd El-Magied, M.; Elshehy, E.; Manaa, E.; Tolba, A.; Atia, A. Kinetics and Thermodynamics Studies on the Recovery of Thorium Ions Using Amino Resins with Magnetic Properties. Ind. Eng. Chem. Res. 2016, 55, 11338-11345. [CrossRef]

56. Abu-zeid, M.; El Aassy, I.; Aly, G.; Abu zeid, E.; Baghdady, A.; Ahmed, A. Geology, petrography and mineralogy of the uraniferous Um Bogma Formation in Gebel Um Hamd, Southwestern Sinai, Egypt. Egypt. J. Geol. 2018, 62, 191-215.

(C) 2019 by the authors. Licensee MDPI, Basel, Switzerland. This article is an open access article distributed under the terms and conditions of the Creative Commons Attribution (CC BY) license (http://creativecommons.org/licenses/by/4.0/). 